\title{
Rule Based Reasoning Untuk Monitoring Distribusi Bahan Bakar Minyak Secara Online dan Realtime menggunakan Radio Frequency Identification
}

\author{
Mokhamad Iklil Mustofa $\mathrm{a}^{\mathrm{a}^{*}}$ \\ ${ }^{\text {a }}$ Sistem Komputer, Sekolah Tinggi Elektronika dan Komputer PAT Semarang \\ Naskah Diterima : 12 Mei 2016; Diterima Publikasi : 15 Mei 2017
}

DOI: $10.21456 /$ vol7iss1pp39-47

\begin{abstract}
The scarcity of fuel oil in Indonesia often occurs due to delays in delivery caused by natural factors or transportation constraints. Theaim of this research is to develop systems of fuel distribution monitoring online and realtime using rule base reasoning method and radio frequency identification technology. The rule-based reasoning method is used as a rule-based reasoning model used for monitoring distribution and determine rule-based safety stock. The monitoring system program is run with a web-based computer application. Radio frequency identification technology is used by utilizing radio waves as an media identification. This technology is used as a system of tracking and gathering information from objects automatically. The research data uses data of delayed distribution of fuel from fuel terminal to consumer. The monitoring technique uses the time of departure, the estimated time to arrive, the route / route passed by a fuel tanker attached to the radio frequency Identification tag. This monitoring system is carried out by the radio frequency identification reader connected online at any gas station or specified position that has been designed with study case in Semarang. The results of the research covering the status of rule based reasoning that sends status, that is timely and appropriate paths, timely and truncated pathways, late and on track, late and cut off, and tank lost. The monitoring system is also used in determining the safety stock warehouse, with the safety stock value determined based on the condition of the stock warehouse rules.
\end{abstract}

Keywords : Rule-Based Reasoning; Radio Frequency Identification; Safety Stock; Fuel Oil

\begin{abstract}
Abstrak
Kelangkaan bahan bakar minyak di Indonesia sering terjadi karena ada keterlambatan pengiriman yang disebabkan oleh faktor alam atau kendala transportasi. Tujuan penelitian ini adalah mengembangkan sistem monitoring distribusi bahan bakar minyak secara online dan realtime dengan metode rule base reasoning dan teknologi radio frequency identification. Metode rule based reasoning digunakan sebagai model penalaran berbasis aturan yang digunakan untuk monitoring distribusi dan menetapkan rule based safety stock. Teknologi radio frequency identification digunakan dengan memanfaatkan gelombang radio sebagai media identifikasi. Teknologi ini digunakan sebagai sistem pelacakan dan pengumpulan informasi dari obyek secara otomatis. Program sistem monitoring dijalankan dengan aplikasi komputer berbasis web. Data penelitian menggunakan data keterlambatan pendistribusian bahan bakar dari terminal bahan bakar ke konsumen. Teknik monitoring mengggunakan waktu keberangkatan, perkiraan waktu sampai, sampai, rute / jalur yang dilewati oleh truk tangki bahan bakar yang terpasang tag radio frequency identification. Sistem monitoring ini dilakukan oleh reader radio frequency identification yang terhubung secara online di setiap Statiun Pengisian Bahan Bakar Umum atau posisi tertentu yang telah dirancang dengan studi kasus di Semarang. Hasil dari penelitian ini berupa status dari penalaran berbasis aturan yang mengirim status, yaitu tepat waktu dan sesuai jalur, tepat waktu dan memotong jalur, terlambat dan sesuai jalur, terlambat dan memotong jalur, dan tangki hilang. Sistem monitoring juga digunakan pada penentuan safety stock warehouse, dengan nilai safety stock ditentukan berdasarkan kondisi basis aturan stok gudang.
\end{abstract}

Kata kunci : Rule-Based Reasoning; Radio Frequency Identification; Safety Stock; Bahan Bakar Minyak

\section{Pendahuluan}

Pada tahun 2014, terdapat kesalahan pendistribusian BBM dari Central Supply Facility Pertamina ke SPBU sebanyak 2.045 (Maulina et al., *) Penulis korespondensi: iklil.mustofa@gmail.com
2014). Kesalahan tersebut dapat berupa penyelewengan distribusi maupun keterlambatan armada pengangkut BBM sampai ke tujuan. Akibat kesalahan tersebut mengakibatkan perusahaan kehilangan kepercayaan oleh para pengusaha penjual 
BBM yang bermitra. Kelangkaan Bahan Bakar Minyak (BBM) berjenis Premium sering terjadi di daerah seluruh Indonesia salah satunya di Stasiun Pengisian Bahan Bakar Umum (SPBU) No.44.595.13 di Kecamatan Karangawen, Kabupaten Demak, Jawa Tengah. Terjadinya kelangkaan BBM tersebut karena ada keterlambatan pengiriman yang disebabkan oleh faktor alam maupun oknum sopir truk tangki BBM yang melakukan penyelewengan, sehingga menuntut pihak SPBU dan TBBM (Terminal Bahan Bakar Minyak) untuk memiliki sistem monitoring distribusi BBM dan konrtrol stok pengaman/safety stock.

Model basis aturan atau rule based merupakan aturan-aturan yang terdapat pada suatu sistem untuk menghasilkan tujuan yang ingin dicapai. Rule based expert system, merupakan aturan yang terdapat dalam sistem pakar yang diadopsi dari seorang pakar untuk mendapatkan kesimpulan dari kondisi yang ada. Basis aturan yang akan digunakan dapat merupakan aturanaturan yang berasal dari seorang pakar di objek penelitian yang diterapakan menjadi SOP (Standart Operational Procedure). Basis aturan sistem pakar pernah digunakan pada sistem peringatan dini gagal jantung berbasis ponsel dengan variabel berat badan, denyut jantung, dan tekanan darah yang mana variabel tersebut didapat dari mewancarai 10 dokter gagal jantung (Seto et al., 2012).

Safety stock memiliki keunggulan dapat memprediksi biaya simpan gudang, memprediksi kebutuhan bahan baku produksi, dan mepercepat pelayanan permintaan. Biaya rata-rata persediaan dapat diminimalisir dengan penggunaan tingkat safety stock secara optimal, sehingga dapat membantu dalam mempercepat tingkat layanan dan pemenuhan kebutuhan pelanggan (Tratar, 2009).

RFID (Radio Frequency Identification) dan Web 2.0 tools dapat digunakan dalam pengelolaan persediaan (inventory) yang mana RFID mempromosikan komunikasi objek melalui sensor dan gelombang radio tanpa melakukan sentuhan secara langsung, sedangkan Web 2.0 tools mempromosikan komunikasi orang melalui ponsel atau komputer dekstop (Mathaba et al., 2011). Sistem monitoring menggunakan teknologi RFID pernah dilakukan untuk melacak posisi pasien di lingkungan rumah sakit karena sering pindahnya pasien terhadap lokasi semula, tetapi masih dalam lingkungan rumah sakit (Cao et al., 2014). Monitoring dengan RFID memiliki kelemahan, jika sistem RFID tidak dapat hidup selama 24 jam, maka akan berakibat terganggunya informasi yang terhubung dalam satu jaringan. Rule based reasoning merupakan penalaran berbasis aturan-aturan yang terdapat pada suatu sistem untuk menghasilkan tujuan yang ingin dicapai.

Tujuan penelitian ini adalah mengembangkan sistem monitoring distribusi bahan bakar minyak secara online dan realtime dengan metode rule base reasoning dan teknologi $R F I D$. Dessain sistem monitoring ini merupakan sistem berbasis aturan untuk monitoring distribusi truk tangki BBM secara online dan realtime menggunakan teknologi RFID yang dapat menentukan kondisi status pengiriman.

\section{Kerangka Teori}

\subsection{Rule Based Reasoning}

Penggunaan rule based reasoning pernah diterapkan pada perusahaan konstruksi baja untuk mendukung pengambilan keputusan tentang efisiensi pemotongan, leadtime, dan ketepatan jadwal proyek untuk mendapatkan biaya pemotongan sekecil mungkin (Venkrataman dan Venkrataman, 2000). Rule based expert system, merupakan aturan yang terdapat dalam sistem pakar yang diadopsi dari seorang pakar untuk mendapatkan kesimpulan dari kondisi yang ada.

Sistem produksi merupakan salah satu representasi pengetahuan yang sangat populer yang pada dasarnya berupa aplikasi aturan/rule yang terdiri dari :

a. Antecedent, yaitu bagian yang mengekspresikan situasi atau premis (pernyataan berawalan $I F$ ).

b. Konsekuen, yaitu bagian yang menyatakan suatu tindakan tertentu atau konklusi yang diterapkan jika suatu kondisi atau premis bernilai benar (pernyataan berawalan THEN).

Konsekuensi atau konklusi yang dinyatakan pada bagian THEN akan dinyatakan benar jika bagian $I F$ pada sistem tersebut juga benar atau sesuai dengan aturan tertentu. Adapun diagram sistem produksi ditunjukkan pada Gambar 1.

Sistem produksi secara umum terdiri dari dua komponen, yaitu: (a) Ruang keadaan, yang berisi keadaan awal, tujuan, dan kumpulan aturan yang digunakan untuk mencapai tujuan; (b) Strategi kontrol, yang berguna untuk mengarahkan bagaimana proses pencarian akan berlangsung dan mengendalikan arah explorasi.

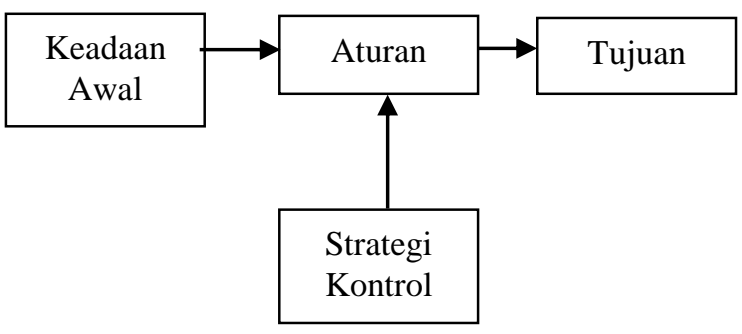

Gambar 1. Sistem Produksi

\subsection{Radio Frequency Identification}

Penggunaan teknologi RFID sebelumnya pernah digunakan pada sistem inventory farmasi di sebuah rumah sakit di Amerika Serikat, teknologi tersebut digunakan untuk memantau secara realtime persedian obat di rumah sakit tersebut (Cakici et al., 201; Condea et al., 2012; Dane et al., 2010). RFID merupakan salah satu solusi sistem pelacakan dan melacak benda-benda baik secara global maupun lokal 
menggunakan tag RFID. Tag RFID adalah Auto-ID prosedur untuk mengidentifikasi obyek secara otomatis dalam wilayah geografis. Hal ini memungkinkan informasi tentang suatu objek yang akan dikumpulkan secara otomatis tanpa harus menangani objek atau memasukkan data secara manual.

RFID menggunakan tag yang berkomunikasi informasi dengan gelombang radio melalui antena pada chip komputer kecil yang melekat pada tag, sehingga benda tersebut dapat diidentifikasi letak dan dapat dilacak (Akintola dan Boyinbode, 2011). RFID merupakan teknologi yang memanfaatkan gelombang radio sebagai media identifikasi suatu objek yang unik, baik benda maupun mahluk hidup. Sistem RFID diberikan pada Gambar 1. RFID terdiri dari beberapa komponen dasar, meliputi tag RFID berguna sebagai $I D$, reader berfungsi melakukan pembacaan tag RFID, dan antena sebagai media perambatan sinyal, pada umumnya antena tergabung dalam tag RFID (Wicaksana et al., 2012).

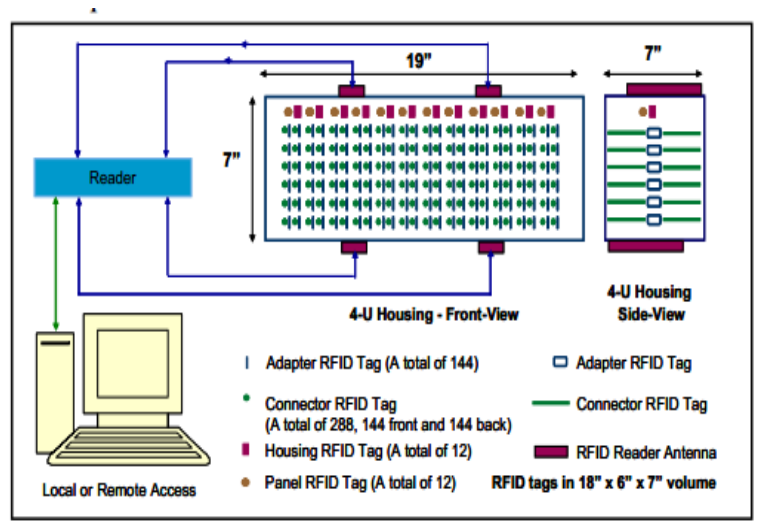

Gambar 2. RFID system for tracking data center connections (Downie et al., 2011)

Cara kerja RFID, yaitu fisik atau tag RFID memiliki nomor seri berbeda - beda atau unik, selajutnya tag RFID (Radio Frequency Identification) akan dipasang di kendaraan pengirim BBM dan di kendaran pengirim tersebut akan didata atau disimpan identitasnya di komputer berdasarkan nomor seri yang tertempel di kendaraan pengirim BBM. Selanjutnya tag RFID itu akan dibaca oleh reader setiap sampai SPBU atau melewati SPBU lainya dan hasilnya akan disimpan di database online yang terkoneksi internet yang terhubung komputer menggunakan layanan broadband, seperti: Telkom, Telkomsel, Xl axiata, Indosat, dan lain-lain.

\subsection{Safety Stock}

Safety stock sangat penting dalam persediaan untuk mengantisipasi unsur ketidakpastian permintaan dan penyediaan. Besar kecilnya safety stock dipengaruhi oleh penggunaan bahan baku rata-rata dan faktor waktu/leadtime (Brander dan Forsberg,
2006). Berikut ini merupakan persamaan yang digunakan dalam menghitung safety stock (Tratar, 2009).

$$
\begin{gathered}
\sigma=\sqrt{\frac{\sum_{i}^{N}\left(d_{i}-\bar{d}\right)^{2}}{N-1}} \\
S S=\alpha . \sigma \sqrt{L T}
\end{gathered}
$$

variabel $N$ adalah jumlah data, $\sigma$ adalah standar deviasi, $d_{i}$ adalah pemakaian ke-i, dan $\bar{d}$ adalah ratarata pemakaian. Variabel SS adalah safety stock, $\alpha$ adalah tingkat service level, dan $L T$ adalah leadtime. Service level dalam suatu perusahaan belum tentu sama dengan perusahaan lainnya, karena service level ditentukan oleh masing-masing perusahaan berdasarkan ketentuan yang dibuat oleh perusahaan itu sendiri. Adapun service level yang dikonversi ke service factor dapat mengikuti aturan Tabel 1 (Celik, 2013).

Tabel 1 Konversi service level ke service factor

\begin{tabular}{cccc}
\hline $\begin{array}{c}\text { Service } \\
\text { Level }\end{array}$ & $\begin{array}{c}\text { Service } \\
\text { Factor }\end{array}$ & Service Level & $\begin{array}{c}\text { Service } \\
\text { Factor }\end{array}$ \\
\hline $50 \%$ & 0 & $90 \%$ & 1,28 \\
$55 \%$ & 0,13 & $91 \%$ & 1,34 \\
$60 \%$ & 0,25 & $92 \%$ & 1,41 \\
$65 \%$ & 0,39 & $93 \%$ & 1,48 \\
$70 \%$ & 0,52 & $94 \%$ & 1,55 \\
$75 \%$ & 0,67 & $95 \%$ & 1,64 \\
$80 \%$ & 0,84 & $96 \%$ & 1,75 \\
$81 \%$ & 0,88 & $97 \%$ & 1,88 \\
$82 \%$ & 0,92 & $98 \%$ & 2,05 \\
$83 \%$ & 0,95 & $99 \%$ & 2,33 \\
$84 \%$ & 0,99 & $99,50 \%$ & 2,58 \\
$85 \%$ & 1,04 & $99,60 \%$ & 2,65 \\
$86 \%$ & 1,08 & $99,70 \%$ & 2,75 \\
$87 \%$ & 1,13 & $99,80 \%$ & 2,88 \\
$88 \%$ & 1,17 & $99,90 \%$ & 3,09 \\
$89 \%$ & 1,23 & $99,99 \%$ & 3,72 \\
\hline
\end{tabular}

\section{Metodologi}

\subsection{Bahan Penelitian}

Bahan penelitian meliputi data eperti sistem distribusi, perlakuan jika terjadi kesalahan pengiriman, dan waktu pengiriman yang diambil dari perusahaan PT. PERTAMINA dan perusahaan rekanan di Jawa Tengah. Data penelitian menggunakan data sample 5 SPBU, yaitu SPBU 44.501.11, SPBU 44.501.16, SPBU 44.501.36, SPBU 44.501.21, dan SPBU 44.595.13. Informasi yang didapatkan dari sample tersebut bahwa transaksi pengiriman pada tanggal 06 Oktober 2015 :

Alat untuk mendukung sistem monitoring ada 2 jenis,. Pertama adalah perangkat keras, antara lain tag RFID, reader RFID, Laptop Fujitsu L510, komputer, dan modem GSM. Kedua adalah perangkat lunak, antara laian OS Windows 8 Pro, Macromedia Dreamweaver, Bahasa pemrograman PHP, dan Database MySQL. 


\subsection{Prosedur Penelitian}

Tahapan pada prosedur penelitian meliputi :

a. Tahapan studi pustaka

Pada tahapan ini pengumpulan jurnal dilakukan untuk mendapatkan informasi dan teori melalui jurnal, literatur, artikel, situs internet, dan karya-karya ilmiah yang telah teruji kebenarannya mengenai penerapan rule based reasoning terhadap monitoring distribusi $\mathrm{BBM}$ secara realtime dan online menggunakan RFID. b. Tahapan identifikasi

Tahapan ini meliputi identifikasi masalah dalam sistem distribusi BBM pada jalur - jalur yang dilalui truk tanki BBM serta melakukan observasi di tempat objek penelitian untuk mendapatkan jenis permasalahan.

c. Tahapan perancangan sistem

Dalam tahapan perancangan sistem ini, dilakukan kegiatan, seperti merancang desain sistem, user interface sistem, dan alur kerja sistem.

d. Tahapan implementasi dan simulasi

Pada tahapan ini, diterapkannya rule based reasoning monitoring distribusi $\mathrm{BBM}$ dan rule based safety stock yang berasal dari objek penelitian ke program sistem monitoring berbentuk aplikasi komputer berbasis web yang telah di-hosting-kan, selanjutnya dilakukan simulasi seperti pada obyek aslinya.

e. Tahapan hasil dan analisis

Tahapan ini menganalisis dari hasil simulasi yang dilakukan sudah sesuai dengan rule based reasoning/aturan-aturan yang menjadi tujuan penelitian apa tidak.

\subsection{Rule Based Persediaan BBM}

Adapun rule based yang digunakan dalam mengantisipasi keamanan stok BBM di TBBM yaitu dengan menerapkan rule based/basis aturan yang telah diterapkan ke dalam aplikasi komputer. Adapun Rule based tersebut disusun sebagai berikut:

a. Rb1: IF (stok and booking) then

Free stock $=$ stok-booking

b. Rb2: IF (Free stock > safety) then

Pesan ("stok dalam keadaan aman")

c. Rb3: IF (Free stock <= safety) then
Pesan ("stok dalam keadaan tidak aman, silakan lakukan pemesanan kembali”).

Variabel stok merupakan variabel yang terdapat pada gudang saat ini, variabel booking merupakan pemesanan yang belum dikirim atau pengiriman yang gagal/tangki hilang, variabel free stock selisih antara stok dengan booking, sedangkan variabel safety stock didapatkan dari perhitungan Persamaan (1) dan Persamaan (2).

\section{Hasil dan Pembahasan}

\subsection{Hasil Penelitian}

Kerangka sistem rule based reasoning untuk monitoring distribusi BBM secara online dan realtime menggunakan RFID ditunjukan Gambar 3. Berikut dideskripsikan hasil dari masukan, proses, dan keluaran dari sistem.

a. Masukan.

Pada tahapan masukan, pihak Admin TBBM Pengapon melakukan input data jenis BBM, data truk tanki BBM yang dipasang Tag RFID, data reader, data konsumen, data SPBU bersama rute yang akan dilalui, data pemasok, dan data user.

b. Proses.

Pada tahapan proses, pihak TBBM Pengapon Melakukan Pemesanan untuk jenis BBM dan kuota yang diinginkan ke Marine, transaksi ini dicatat sebagai pemesanan ke marine, selanjutnya pihak TBBM menerima jenis BBM yang telah dipesan untuk dimasukan ke dalam gudang masuk, transaksi ini dicatat sebagai gudang masuk. Seiring dengan hal tersebut pihak pemilik SPBU melakukan pemesanan secara online ke TBBM Pengapon untuk SPBU yang dimilikinya, selanjutnya transaki ini akan tercatat di bagian gudang keluar dengan status booking karena belum terjadi pengiriman. Selanjutnya pihak operator melakukan pengiriman berdasarkan pemesanan yang dilakukan oleh pemilik SPBU sekaligus memberikan nomor pengiriman dan menentukan truk yang sudah terpasang tag RFID untuk memuat BBM ke tujuan pemesanan.

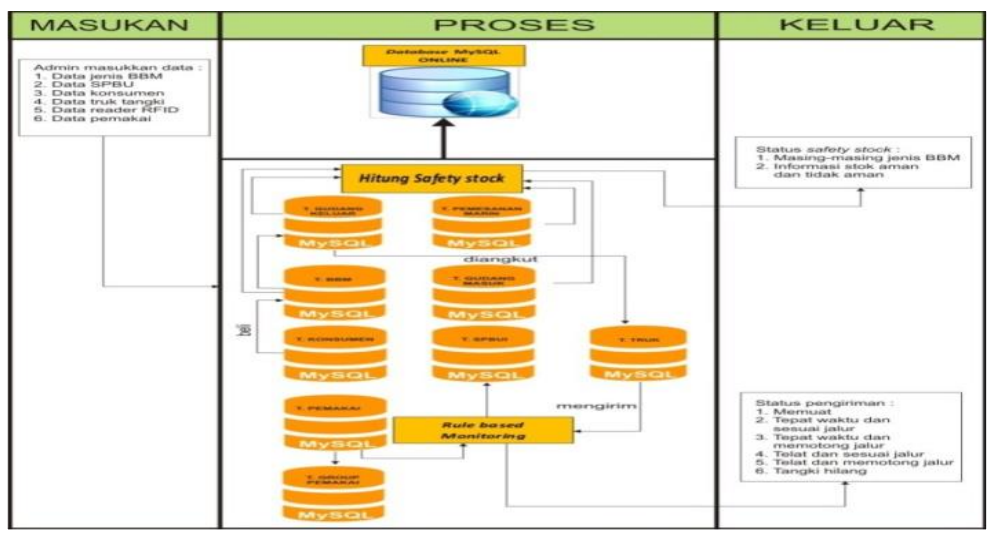

Gambar 3. Kerangka sistem monitoring distribusi BBM secara online dan realtime 


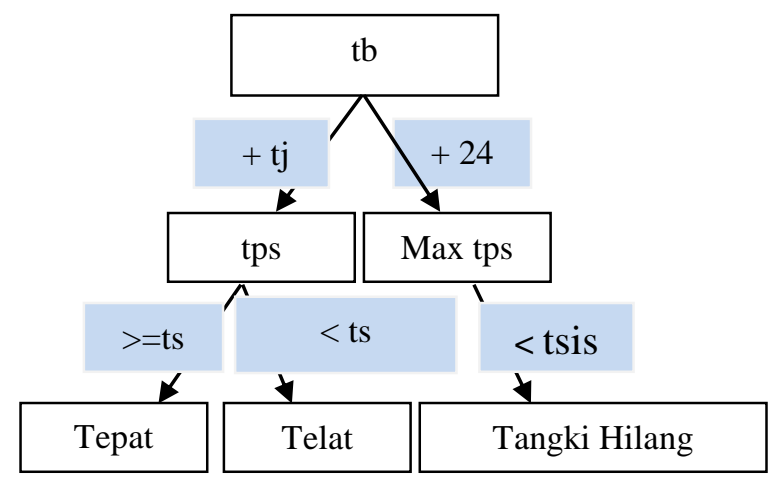

Gambar 4. Rule based reasoning berdasarkan waktu berangkat

Reader akan membaca tag RFID pada truk BBM yang melewati reader. dan memasukkan data waktu dari pembacaan reader-reader tersebut ke tabel monitoring dalam database server yang terkoneksi internet secara online dan realtime. Berdasarkan data tersebut pada database server akan diketahui waktu berangkat dan waktu sampai saat di SPBU tujuan berdasarkan waktu sistem dan reader di masingmasing SPBU, dan mencocokkan inputan tersebut dengan aturan yang ditunjukkan pada Gambar 4, Gambar 5, dan Gambar 6, sehingga akan diketahui status dari pengiriman tersebut dan pihak TBBM dapat menentukan tingkat safety stock berdasarkan Persamaan (1) dan Persamaan (2). Aturan yang dipengaruhi beberapa parameter, seperti waktu pemesanan BBM ke Marine, waktu BBM masuk gudang, rata-rata dari jumlah pengiriman BBM, dan service level yang telah ditentukan perusahaan sebesar 95\% yang akan dieksekusi setiap 4 hari sekali.

Adapun rule-based reasoning monitoring distribusi BBM sebagai berikut: (a) Variabel yang digunakan adalah $\mathrm{tb}=$ waktu berangkat, $\mathrm{tj}=$ estimasi waktu jarak, tps = prediksi waktu sampai, ts = waktu sampai, max tps = maximum prediksi waktu sampai, dan tsis = waktu sistem. RF01 = reader di tikungan alfa, RF02=reader di SPBU 44.501.16, RF03 = reader di SPBU 44.501.21, RF04 = reader di SPBU 44.501.36, RF05 = reader di SPBU 44.501.11, dan RF06 = reader di SPBU 44.595.13; (b) Rule based reasoning pada distribusi BBM berdasarkan waktu berangkat ditunjukkan Gambar 4.

Prediksi waktu sampai (tps) merupakan penjumlahan waktu berangkat dengan estimasi waktu jarak (tj). Jika waktu sampai (ts) kurang dari sama dengan prediksi waktu sampai (tps), maka status pengiriman "tepat waktu". Jika waktu sampai (ts) lebih dari prediksi waktu sampai (tps) dan kurang dari sama dengan maximum prediksi waktu sampai (max tps), maka status pengiriman "telat". Untuk maximum prediksi waktu sampai merupakan waktu berangkat (tb) ditambah 24 jam, dan jika tangki datang sampai tujuan (tsis) melebihi "max tps", maka status pengiriman "tangki hilang atau tidak terbaca" oleh reader.

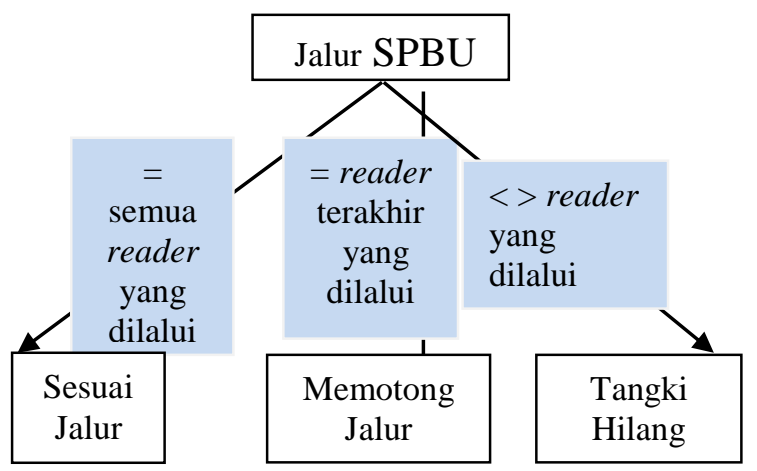

Gambar 5. Rule based reasoning berdasarkan jalur tempuh

Prediksi waktu sampai (tps) merupakan penjumlahan waktu berangkat dengan estimasi waktu jarak (tj). Jika waktu sampai (ts) kurang dari sama dengan prediksi waktu sampai (tps), maka status pengiriman "tepat waktu". Jika waktu sampai (ts) lebih dari prediksi waktu sampai (tps) dan kurang dari sama dengan maximum prediksi waktu sampai (max tps), maka status pengiriman "telat". Untuk maximum prediksi waktu sampai merupakan waktu berangkat (tb) ditambah 24 jam, dan jika tangki datang sampai tujuan (tsis) melebihi "max tps", maka status pengiriman "tangki hilang atau tidak terbaca" oleh reader.

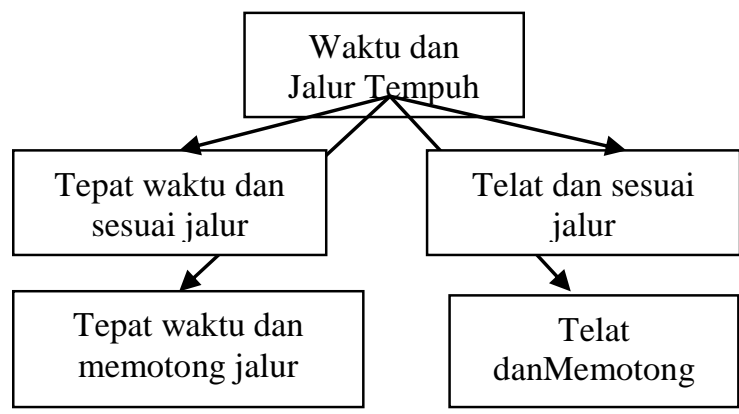

Gambar 6. Rule based berdasarkan aturan waktu dan aturan jalur tempuh

Rule based reasoning berdasarkan jalur tempuh ditunjukkan Gambar 5. Jalur SPBU terdiri dari satu atau lebih reader RFID. Jika semua reader yang dilalui truk selama pengiriman sama dengan semua reader di jalur SPBU tujuan, maka status pengiriman "sesuai jalur", jika reader yang dilalui truk selama pengiriman minimal hanya reader terakhir yang sama dengan reader di jalur SPBU tujuan, maka status pengiriman "memotong jalur", dan jika sama sekali tidak ada kesamaan antara reader yang dilalui dengan reader di jalur SPBU, maka status pengiriman "tangki hilang". Basis aturan status berdasarkan aturan waktu dan aturan jalur tempuh ditunjukkan Gambar 6. 


\begin{tabular}{|c|c|c|c|c|c|c|c|}
\hline Nomor & Tangga1 & Tujuan & Alamat & Kapasitas & $\begin{array}{c}\text { Jam } \\
\text { Berangkat }\end{array}$ & $\begin{array}{l}\text { Waktu } \\
\text { Tiba }\end{array}$ & Status Kirim \\
\hline \multirow{2}{*}{ KROO00026 } & \multirow{2}{*}{$06 / 10 / 16$} & \multirow{2}{*}{44.501 .16} & \multirow{2}{*}{$\begin{array}{l}\text { J1. Pengapon, } \\
\text { Kota Semarang }\end{array}$} & \multirow{2}{*}{32} & \multirow{2}{*}{$10: 42: 36$} & $06 / 10 / 16$ & \multirow{2}{*}{$\begin{array}{c}\text { Tepat Waktu } \\
\text { dan Sesuai } \\
\text { Jalur }\end{array}$} \\
\hline & & & & & & $10: 44: 49$ & \\
\hline \multirow{2}{*}{ KROO000027 } & \multirow{2}{*}{$06 / 10 / 16$} & \multirow{2}{*}{44.501 .36} & \multirow{2}{*}{$\begin{array}{l}\text { J1. Kaligawve 14, } \\
\text { Semarang }\end{array}$} & \multirow{2}{*}{24} & \multirow{2}{*}{$12: 45: 49$} & $06 / 10 / 16$ & \multirow{2}{*}{$\begin{array}{c}\text { Tepat Waktu } \\
\text { dan Memotong } \\
\text { Jalur }\end{array}$} \\
\hline & & & & & & $12: 49: 38$ & \\
\hline \multirow{2}{*}{ KROO00028 } & \multirow{2}{*}{$06 / 10 / 16$} & \multirow{2}{*}{44.501 .21} & \multirow{2}{*}{$\begin{array}{l}\text { J1. Dr. Cipto } 52, \\
\text { Semarang }\end{array}$} & \multirow[b]{2}{*}{ s } & \multirow{2}{*}{$12: 52: 58$} & $06 / 10 / 16$ & \multirow{2}{*}{$\begin{array}{l}\text { Telat dan } \\
\text { Sesuai Jalur }\end{array}$} \\
\hline & & & & & & $13: 00: 03$ & \\
\hline \multirow{2}{*}{ KROO00029 } & \multirow[b]{2}{*}{$06 / 10 / 16$} & \multirow[b]{2}{*}{44.501 .11} & \multirow[b]{2}{*}{ J1. Kaligawe } & \multirow[b]{2}{*}{24} & \multirow[b]{2}{*}{$13: 01: 33$} & $06 / 10 / 16$ & \multirow{2}{*}{$\begin{array}{l}\text { Telat dan } \\
\text { Memotong } \\
\text { Jalur }\end{array}$} \\
\hline & & & & & & $13: 12: 46$ & \\
\hline \multirow[b]{2}{*}{ KRo000030 } & \multirow[b]{2}{*}{$06 / 10 / 16$} & \multirow[b]{2}{*}{44.595 .13} & \multirow{2}{*}{$\begin{array}{c}\text { J1. Raya } \\
\text { Karangawen } \\
\text { Demak }\end{array}$} & \multirow[b]{2}{*}{16} & \multirow[b]{2}{*}{$13: 14: 19$} & $06 / 10 / 16$ & \multirow{2}{*}{$\begin{array}{c}\text { Tepat Waktu } \\
\text { dan Sesuai } \\
\text { Jalur }\end{array}$} \\
\hline & & & & & & $13: 45: 19$ & \\
\hline \multirow[b]{2}{*}{ KRO000031 } & \multirow[b]{2}{*}{$06 / 10 / 16$} & \multirow[b]{2}{*}{44.595 .13} & \multirow{2}{*}{$\begin{array}{c}\text { J1. Raya } \\
\text { Karangawen } \\
\text { Demak }\end{array}$} & & & $06 / 10 / 16$ & Tangki Hilang \\
\hline & & & & 32 & $13: 18: 21$ & $\ldots$ & $\begin{array}{l}\text { dan Lakukan } \\
\text { Pengiriman } \\
\text { Kembali }\end{array}$ \\
\hline
\end{tabular}

Gambar 7. Keluaran rule based reasoning status pengiriman BBM

Tabel 2. Hasil/output status safety stock BBM

\begin{tabular}{|c|c|c|c|c|c|c|}
\hline Kode & Jenis BBM & Stok & Safety stock & Booking & Free & Status \\
\hline KB01 & Premium & 11.143 & 4.152 & 0 & 11.143 & Stok Aman \\
\hline KB02 & Solar & 17.539 & 1.597 & 0 & 17.539 & Stok Aman \\
\hline KB03 & Kerosin & 3.807 & 93 & 0 & 3.807 & Stok Aman \\
\hline KB04 & Pertamax & 534 & 914 & 0 & 534 & $\begin{array}{c}\text { Stok tidak aman } \\
\text { lakukan } \\
\text { pemesanan } \\
\text { kembali }\end{array}$ \\
\hline KB05 & Pertalite & 3.511 & 124 & 0 & 3.511 & Stok Aman \\
\hline
\end{tabular}

Tabel 3. Status kirim pada uji coba sistem monitoring distribusi BBM

\begin{tabular}{|c|c|c|c|}
\hline No Kirim & SPBU & Status kirim & Validasi \\
\hline KR0000026 & 44.501 .16 & $\begin{array}{l}\text { Tepat waktu dan } \\
\text { sesuai jalur }\end{array}$ & $\sqrt{ }$ \\
\hline KR0000027 & 44.501 .36 & $\begin{array}{l}\text { Tepat waktu dan } \\
\text { memotong jalur }\end{array}$ & $\sqrt{ }$ \\
\hline KR0000028 & 44.501 .21 & $\begin{array}{l}\text { Telat dan sesuai } \\
\text { jalur }\end{array}$ & $\sqrt{ }$ \\
\hline KR0000029 & 44.501 .11 & $\begin{array}{l}\text { Telat dan } \\
\text { memotong jalur }\end{array}$ & $\sqrt{ }$ \\
\hline KR0000030 & 44.595 .13 & $\begin{array}{l}\text { Tepat waktu dan } \\
\text { sesuai jalur }\end{array}$ & $\sqrt{ }$ \\
\hline KR0000031 & 44.595 .13 & $\begin{array}{l}\text { Tangki hilang } \\
\text { dan lakukan } \\
\text { pengiriman } \\
\text { kembali }\end{array}$ & $\sqrt{ }$ \\
\hline
\end{tabular}

\section{c. Keluaran}

Pada tahap keluaran, sistem akan menampilkan status pengiriman, seperti tepat waktu dan sesuai jalur, tepat waktu dan memotong jalur, telat dan sesuai jalur, telat dan memotong jalur, dan tangki hilang serta safety stock TBBM. Keluaran sistem monoring disgtribusi BBM diberikan ada Gambar 7, dan hasil sebagai keluaran status safety stock BBM diberikan pada Tabel 3 .

\subsection{Pembahasan}

Penelitian dilakukan dengan menggunakan data sample 5 SPBU, yaitu SPBU 44.501.11, SPBU 44.501.16, SPBU 44.501.36, SPBU 44.501.21, dan SPBU 44.595.13. Hasil Hasil penelitian status kirim pada uji coba sistem monitoring distribusi BBM diberikan pada Tabel 3.

a. Pengiriman dengan nomor kirim "KR0000027" ke SPBU 44.501.36 mengalami status pengiriman "tepat waktu dan memotong jalur".

1) Rule based reasoning berdasarkan waktu berangkat.

- $\quad \mathrm{tb}=12: 45: 49$

- $\mathrm{tj}=5$ menit

- $\quad$ tps $=12: 50: 49$

- $\mathrm{ts}=12: 49: 38$

- $\quad \max$ tps $=\mathrm{tb}+24$ jam $=12: 45: 49+24$ jam $=12: 45: 49$ di tanggal 7 Oktober 2015.

- kesimpulan :

ts $<=$ tps , $12: 49: 38<=12: 50: 49 \mathrm{di}$ tanggal 7 Oktober 2015, maka kesimpulannya tepat waktu.

2) Rule based reasoning berdasarkan jalur tempuh. 
- Jalur SPBU, yaitu RF01, RF04.

- Jalur reader yang sudah dilalui, yaitu RF02, RF04.

- Jalur SPBU sama dengan jalur reader terakhir yang dilalui, yaitu RF04, maka kesimpulannya memotong jalur.

3) Rule based reasoning berdasarkan waktu dan jalur tempuh.

- Kesimpulan rule based berdasarkan waktu berangkat, memiliki kondisi tepat waktu.

- Kesimpulan rule based berdasarkan jalur tempuh, memiliki kondisi memotong jalur.

- Maka hasil akhir adalah tepat waktu dan memotong jalur.

b. Pengiriman dengan nomor kirim "KR0000028" ke SPBU 44.501.21 mengalami status pengiriman dalam kondisi "telat dan sesuai jalur".

1) Rule based reasoning berdasarkan waktu berangkat.

- $\quad \mathrm{tb}=12: 52: 58$

- $\mathrm{tj}=6$ menit

- $\quad$ tps $=12: 58: 58$

- $\mathrm{ts}=13: 00: 03$

- $\quad \max$ tps $=\mathrm{tb}+24 \mathrm{jam}=12: 52: 58+24 \mathrm{jam}$ $=12: 52: 58$ di tanggal 7 Oktober 2015 .

- kesimpulan : tps $<$ ts $<=$ max tps , 12:52:58 $<13: 00: 03<=12: 52: 58$ di tanggal 7 Oktober 2015, maka kesimpulannya telat.

2) Rule based reasoning berdasarkan jalur tempuh.

- Jalur SPBU, yaitu RF01, RF03.

- Jalur reader yang sudah dilalui, yaitu RF01, RF03.

- Jalur SPBU sama dengan jalur semua reader yang dilalui, yaitu RF01 dan RF03, maka kesimpulannya sesuai jalur.

3) Rule based reasoning berdasarkan waktu dan jalur tempuh.

- Kesimpulan rule based berdasarkan waktu berangkat, memiliki kondisi telat.

- Kesimpulan rule based berdasarkan jalur tempuh, memiliki kondisi sesuai jalur.

- Maka hasil akhir adalah telat dan sesuai jalur.

c. Pengiriman dengan nomor kirim "KR0000029" ke SPBU 44.501.11 mengalami status pengiriman dalam kondisi "telat dan memotong jalur".

1) Rule based reasoning berdasarkan waktu berangkat.

- $\quad \mathrm{tb}=13: 01: 33$

- $\quad \mathrm{tj}=7$ menit

- $\quad$ tps $=13: 08: 33$

- $\quad$ ts $=13: 12: 46$
- $\quad \max$ tps $=\mathrm{tb}+24$ jam $=13: 01: 33+24$ jam $=13: 01: 33$ di tanggal 7 Oktober 2015.

- kesimpulan :

tps $<$ ts $<=$ max tps , 13:08:33<13:12:46<=13:01:33 di tanggal 7 Oktober 2015, maka kesimpulnnya telat.

2) Rule based reasoning berdasarkan jalur tempuh.

- Jalur SPBU, yaitu RF01, RF04, RF05.

- Jalur reader yang sudah dilalui, yaitu RF01, RF03, RF05

- Jalur SPBU sama dengan jalur reader terakhir yang dilalui, yaitu RF05, maka kesimpulannya memotong jalur.

3) Rule based reasoning berdasarkan waktu dan jalur tempuh.

- Kesimpulan rule based berdasarkan waktu berangkat, memiliki kondisi telat.

- Kesimpulan rule based berdasarkan jalur tempuh, memiliki kondisi memotong jalur.

- Maka hasil akhir adalah telat dan memotong jalur.

d. Pengiriman dengan nomor kirim "KR0000030" ke SPBU 44.595.13 mengalami status pengiriman dalam kondisi "tepat waktu dan sesuai jalur".

1) Rule based reasoning berdasarkan waktu berangkat.

- $\quad \mathrm{tb}=13: 14: 19$

- $\mathrm{tj}=45$ menit

- $\quad$ tps $=13: 59: 19$

- $\mathrm{ts}=13: 45: 19$

- $\quad \max$ tps $=\mathrm{tb}+24$ jam $=13: 14: 19+24$ jam $=13: 14: 19$ di tanggal 7 Oktober 2105.

- kesimpulan : ts $<=$ tps, 13:45:19<=13:59:19, maka kesimpulannya tepat waktu.

2) Rule based reasoning berdasarkan jalur tempuh.

- Jalur SPBU, yaitu RF01, RF04, RF05, RF06

- Jalur reader yang sudah dilalui, yaitu RF01, RF04, RF05, RF06

- Jalur SPBU sama dengan jalur semua reader yang dilalui, yaitu RF01, RF04, RF05, RF06, maka kesimpulannya sesuai jalur.

3) Rule based reasoning berdasarkan waktu dan jalur tempuh.

- Kesimpulan rule based berdasarkan waktu berangkat, memiliki kondisi telat.

- Kesimpulan rule based berdasarkan jalur tempuh, memiliki kondisi memotong jalur. 
- Maka hasil akhir adalah tepat waktu dan sesuai jalur.

e. Pengiriman dengan nomor kirim "KR0000031" ke SPBU 44.595.13 mengalami status pengiriman dalam kondisi "tangki hilang dan lakukan pengiriman kembali”.

1) Rule based reasoning berdasarkan waktu berangkat.

- $\mathrm{tb}=13: 18: 21$

- $\mathrm{tj}=45$ menit

- $\quad$ tps $=14: 03: 21$

- $\mathrm{ts}=. . ?$

- $\quad$ tsis $=14: 10: 24$ di tanggal 7 Oktober 2015.

- $\quad \max$ tps $=\mathrm{tb}+24 \mathrm{jam}=13: 18: 21+24 \mathrm{jam}$ $=13: 18: 21$ di tanggal 7 Oktober 2015 .

- kesimpulan : tsis $>\max$ tps $=14: 10: 24>13: 18: 21$ maka kesimpulannya tangki hilang/ tidak terbaca.

2) Rule based reasoning berdasarkan jalur tempuh. (1) Jalur SPBU, yaitu RF01, RF04, RF05, RF06Jalur reader yang sudah dilalui ,yaitu RF01, RF04, RF05, RF03; (2) Jalur SPBU tidak sama dengan jalur reader yang dilalui, yaitu RF03 maka kesimpulannya tangki hilang.

Guna memonitoring safety stock, dilakukan pengambilan sample 5 jenis BBM, yaitu premium, solar, pertamax, kerosin/minyak tanah, dan pertalite. Dalam hasil penelitian untuk jenis pertamax mengalami stok tidak aman karena stok dalam posisi 534, safety stock dalam posisi 914, dan booking dalam posisi 0 , sehingga free stock dalam posisi 534 didapat dari selisih antara stok dikurangi booking (534-0) karena sesuai Rb3 safety stock pada sub bab 3.4, maka didapatkan status "stok tidak aman dan lakukan pemesanan kembali”, sehingga bagian PP (penimbunan dan penyaluran) harus melakukan pemesanan kembali ke marine. Selain jenis pertamax, jenis BBM lainnya masih dalam status "stok aman".

\section{Kesimpulan}

Monitoring bahan bakar minyak dapat dilakukan melalui sistem monitoring yang dirancang menggunakan metode rule based reasoning untuk monitoring distribusi BBM secara online dan realtime dengan RFID. Kombinasi rule based reasoning dengan teknologi RFID dapat memonitoring database secara online, sehingga dapat menghasilkan status pengiriman secara online dan realtime, status pengiriman ini, yaitu tepat waktu dan sesuai jalur, tepat waktu dan memotong jalur, telat dan sesuai jalur, telat dan memotong jalur, serta tangki hilang dan lakukan pengiriman kembali jika lebih dari 24 jam.

Penentuan safety stock BBM didapatkan dari kombinasi service level dengan rata-rata penjualan per jenis BBM yang terjadi selama rentang waktu yang ditentukan perusahaan. Penelitian ini mengambil service level dari perusahaan sebesar $95 \%$ dan menghasilkan stok tidak aman untuk jenis BBM Pertamax, yaitu stok dalam posisi 534, safety stock dalam posisi 914, dan booking dalam posisi 0 , sehingga free stock dalam posisi 534 didapat dari selisih antara stok dikurangi booking. Sistem ini tidak akan setabil jika perawatan sistem tidak terjaga dengan baik, seperti komputer client untuk reader harus terjaga, jika terjadi kerusakan maka sistem tidak berjalan sesuai harapan.

\section{Daftar Pustaka}

Akintola, K.G., Boyinbode, O.K., 2011. The Place Of Emerging RFID Technology in National Scurity and Development, International Journal of Smart Home 5 (2).

Brander, P., Forsberg, R., 2006. Determination of Safety Stock For Cyclic Schedules With Stochastic Demands, International Journal Production Economics 104, 271-295.

Cakici, O.E., Groenevelt, H., Seidman, A., 2011. Using RFID For The Management Pharmaceutical Inventory - System Optimitation And Shrinkage Control, William E. Simon Graduate School Of Business 51, 842 - 852.

Cao, Q., Jones, D.R., Sheng, H., 2014. Contained nomadic information environtments: Technology organization, and environtment influences on adoption of hospital RFID patient tracking, Information and Management 51, 225-239.

Celik, O., 2013. Optimization Of Safety Stock Level In A Manufacturing Company, Final Project, School Of Industrial Engineering And Telecommunication, University Of Cantrabia.

Condea, C., Frederick, T., Elgar, F., 2012. RFID Enabled Self Replenishment With Backroom Monitoring In Retail Stores, Decission Support Systems 52, 839-849.

Dane, H., Michael, K., Wamba., S.F., 2010. RFIDenabled Inventory Control Optimization: A Proof of Concept in a Small-to-Medium Retailer, Faculty Of Engineering and Informatic Sciences, University of Wollongong Research Online.

Downie, J., Matthew, W., Trice, J., Vemagiri, J., Blaignan, V., Suber, C., Chamarti, A ., Pollard, S., McCollum, R., Wagner, R.E., 2011. RFID Tag Reablity for Tracking Fiber Optic Connections in Data Center, IEEE International Conference On RFID Technologies and Applications, NY, September 15, 16, 230-235.

Mathaba, S., Dlodlo, N., Smith, A., Adigun, M., 2011. The Use of RFID and Web 2.0 Technologies to Improve Inventory Management in South African Enterprises, Scientific For Industrial Research, Meraka Institute, Electronic Journal Information Systems Evaluation 14 (2). 
Maulina, S., Nazaruddin, M., dan Ikhsan, S., 2014. Penentuan Rute Pendistribusian BBM Untuk Meminimalkan Keterlambatan Pendistribusian Central Supplay Facilities, e-Jurnal Teknik Industri FT USU 3 (2), 58-66.

Seto, E., Leonard, K.J., Caffazo, J.A.,Barnsley, J., Masino, C., Ross, H.j., 2012 Developing healthcare rule-based expert systems:Case study of a heart failure telemonitoring system, International Journal of Medical Informatic 81, 556-565.
Tratar, L.F., 2009. Minimising Inventory Costs By Properly Choosing The Level Of Safety Stock, Economic And Business Review 11 (2), 109-117.

Venkrataman, R., Venkrataman, S., 2000. Rule-Based System Aplication For A Technical Problem In Inventory Issue, Artificial Intelligence In Engineering 14, 143-152.

Wicaksana, A., Utama, H.S., 2014. Building Security Door System Using RFID (Radio Frequency Identification) And Arduino Severino, e-Jurnal Teknik Informatika STMIK Amikom, Yogyakarta. 